\title{
Laser Raman micro-spectroscopy of Proterozoic and Palaeozoic organic-walled microfossils (acritarchs and prasinophytes) from the Ghadamis Basin, Libya and Volta Basin, Ghana
}

\author{
Marie-Claire Dhamelincourt $^{\mathrm{a}}$, Marco Vecoli ${ }^{\mathrm{b}, *}$, Alberto Mezzetti ${ }^{\mathrm{a}, \mathrm{c}}$, Christian Cesari $^{\mathrm{b}}$, \\ Gerard Versteegh ${ }^{\mathrm{d}}$ and Armelle Riboulleau ${ }^{\mathrm{b}}$ \\ ${ }^{a}$ Université Lille 1, LASIR UMR 8516, Villeneuve d'Ascq, France \\ ${ }^{\mathrm{b}}$ Université Lille 1, GEOSYSTEMES FRE 3298 CNRS, Villeneuve d'Ascq, France \\ ${ }^{\mathrm{c}}$ Service de Bioénergétique, Biologie Structurale et Mécanismes, IBiTec-S, CEA-Saclay, Gif-sur-Yvette, \\ France \\ ${ }^{\mathrm{d}}$ MARUM, Universität Bremen Postfach, Bremen, Germany
}

\begin{abstract}
Laser Raman microspectroscopy was used as a microchemical analysis technique to characterize the wall chemistry of organic-walled microfossils (acritarchs and prasinophytes) extracted from Proterozoic (Tonian: ca. 900 Myr) and early Palaeozoic (Silurian: ca. 420 Myr) marine sediments in the Volta Basin of Ghana, and the Ghadamis Basin of Libya, respectively. Raman spectra of Proterozoic acritarchs show spectral features characteristic of kerogenous compounds at $\sim 1350$ and $\sim 1600 \mathrm{~cm}^{-1}$, consistently with previously published reports. In addition, spectra from prasinophyte algae from the Silurian sample also show an interesting spectral feature at $\sim 1707 \mathrm{~cm}^{-1}$ indicative of carbonyl moieties.

Broadly speaking, shape and position of Raman bands appear to depend on the nature of the specimen considered, suggesting that laser micro-Raman analysis can potentially be used to establish phylogenetic relationships (high-rank taxonomy) among the main groups of pre-Cambrian to Palaeozoic palynomorphs.
\end{abstract}

Keywords: Acritarchs, neoproterozoic, palaeozoic, laser micro-Raman, kerogen, sporopollenin

\section{Introduction and scope of study}

Acritarchs are a taxonomically informal group of morphologically complex organic-walled microfossils $(10-200+\mu \mathrm{m})$ which are found in large abundance (commonly in the order of $10^{5}$ specimens per gram of rock) in fine-grained marine sediments of Proterozoic $(2500-542 \mathrm{Myr}$ ago $[9,12,14,16])$ and Palaeozoic (542-251 Myr ago [4]) age. Most acritarchs from Proterozoic and Palaeozoic rocks are interpreted as unicellular photosynthetic protists of unknown polyphyletic origin, although it is now recog-

\footnotetext{
*Corresponding author: M. Vecoli, Université Lille 1, GEOSYSTEMES FRE 3298 CNRS, Bât SN5, F-59655 Villeneuve d'Ascq, France. Tel.: +33 3 20434136; Fax: +33 3 20434910; E-mail: marco.vecoli@univ-lille1.fr.
} 
nized that representatives of the Prasinophyceae are also included within the acritarchs [4]. The evolutionary patterns and abundance fluctuations of acritarchs in the sedimentary records have been put in relation with changes in ocean chemistry [15,18], global glaciations [10], the diversification of metazoans [23,28], and variations in atmospheric $\mathrm{CO}_{2}$ concentration [24]. Acritarchs are also associated to accumulation of organic-rich sediments and petroleum source-rocks [29]. However, persisting uncertainties over the biological affinities and phylogenetic relationships of these Proterozoic to Palaeozoic microfossils impede further progress in the study of evolutionary patterns of oceanic phytoplankton (the "acritarch vs. dinocyst" debate: $[4,13])$ as well as in the exact palaeobiological and phylogenetic attribution of certain types of "enigmatic" palynomorphs (e.g., "cryptospores" in Cambrian-aged sediments [25]). Current understanding of acritarch palaeobiology is primarily based on morphological criteria $([4,13]$ and including ultrastructural study of cell walls $[26,30])$ and on analyses of distributional patterns in the sedimentary record [27]. For a long time, the lack of detailed knowledge in the chemical composition of modern algae, fungi and spores from land plants has been the major impediment to understanding affinities of organic-walled microfossils [4]. The importance of sporopollenin-compounds as the more widespread biopolymers within the green algae seems well established $[4,6]$, and these were found both in the vegetative as well as the reproductive (resting cyst) stages of green algae [6]. Chromatography pyrolysis patterns from a sedimentary rock entirely composed of accumulation of fossil Gloecapsomorpha prisca Zalessky 1917 allowed to support affinity with the cyanobacteria rather than the green algae [7]. NMR spectra were obtained from concentrates of Palaeozoic megaspores isolated from sporangia and compared with spectra from modern plants [8], highlighting diagenetic changes in the chemical composition of spore wall through geological times. The above examples, also discussed in detail in [4], have highlighted the importance of chemical characterization for providing evidence of palaeobiological affinities of fossil material, however the exceptional fossil material in the first case [7], and the time-consuming technique used in the second example [8] make these investigations quite unique and not applicable routinely on small samples. Recent advances in the study of early protist palaeobiology have highlighted the potential of combined microscopy and microchemical characterization of single microfossils, either in situ or in isolated specimens. Among the various techniques newly applied to the study of acritarch palaeobiology, micro-Raman spectroscopy holds considerable potential as a non-intrusive and non-destructive analytical technique capable of providing crucial information about the microchemical structure of organic-walled microfossils [1,21]. Recent previous studies on micro-Raman spectroscopy on Archean to Proterozoic fossil material have been principally applied (a) to demonstrate the correlation between optically discernible morphologies and kerogenous composition of permineralized fossil microorganisms, especially in situ [20-22], (b) as a means to show evidence of biogenicity of microfossil-like structure in Earth's oldest microfossils and - potentially - in extraterrestrial material [2,21], (c) to tentatively establish phylogenetic relationships between Proterozoic acritarchs and dinoflagellates [1].

The present study is part of a larger project aiming at elucidating the nature, biological affinities, and palaeoecological role of the major groups of pre-Cambrian to Palaeozoic palynomorphs, involving different and complementary analytical techniques; in this paper we present preliminary results on micro-Raman spectroscopy on exceptionally well preserved organic-walled microfossils from two assemblages of differing geological age (Silurian and early Neoproterozoic) with the aims of (1) improving the existing database of microchemical analyses on single-specimens of acritarchs of Neoproterozoic to Palaeozoic age and compare the results vis-à-vis the existing literature data; (2) highlighting possible effects of kerogen degradation through geological times; (3) contributing to assess the potential of mi- 
crochemical characterization for taxonomic assignment of microfossils and/or enigmatic carbonaceous structures in sedimentary to metamorphic rocks.

\section{Materials and methods}

Two study samples were collected from: (1) a continuously cored stratigraphic borehole in the Libyan subsurface, at depth of $-2130 \mathrm{~m}$ (A1-61 borehole, Ghadamis Basin), and (2) a fresh quarry cut outcrop in the Volta Basin of Ghana (base of the Anyaboni Formation, Kwahu/Bombouaka Supergroup). Sample 1 is Late Silurian in age (ca. $420 \mathrm{Myr}$ ) based on its chitinozoan and miospore content $([11,19]$ and unpublished personal data: M. Vecoli); Sample 2 is of early Neoproterozoic age (850-900 Myr) based on palynological content and supported by available zircon geochronology data [5]. Both samples consists of finely laminated dark grey to olive green shales with $\mathrm{cm}$-thick interbeds of fine grained sandstones and show no or very weak (Sample 2) signs of weathering, and no evidence of oxidation.

Organic-walled microfossils were extracted from the two sedimentary rock samples using a standard palynological maceration technique, involving the dissolution of the mineral rock matrix (carbonates and silicates) by use of concentrated $\mathrm{HCl}$ and $\mathrm{HF}$, isolation of the organic residue from residual heavy minerals by density contrast separation, and filtration of the organic concentrate using $15 \mu \mathrm{m}$ mesh-size filter for removal of fine-grained amorphous organic matter. The organic residue was placed on a microscope slide, left to dry and covered with a glass cover-slip for optical microscopy observation; the same procedure but without covering of residue with cover-slip was used for micro-Raman analyses. Samples contained very abundant and diverse palynological assemblages, comprising acritarchs, chitinozoans and miospores in Sample 1, and exclusively acritarchs in Sample 2. Preservation of organic matter was very good (Sample 1) to good (Sample 2), based on microfossils' colour (varying from amber to amber brown in Sample 1, and amber brown to brown in Sample 2), and on excellent preservation of very fine morphological detail and sculptural elements. Thermal maturity of organic matter was assessed by observation of kerogen and microfossils colour and comparison with published tables of colour-index of thermal maturity [17] which resulted in an estimated early mature organic matter (beginning of oil generation) for the study samples.

Raman spectra were obtained by means of a laser micro-Raman spectrometer LABRAM (J.Y. Horiba). The samples were exposed to an He-Ne Laser $(632.8 \mathrm{~nm})$ at a laser power of less $1 \mathrm{~mW}$ to avoid radiation damage and minimize laser induced heating; in these conditions, the time of the analysis was of a few minutes (accumulation time of $30 \mathrm{~s}$ and 10 scans). A $100 \times$ objective lens was used, so the spatial resolution of the Raman analysis was $1 \mu \mathrm{m}$. Raman spectra were recorded in the $1000-1800 \mathrm{~cm}^{-1}$ range.

\section{Results}

Typical micro-Raman spectra of analyzed microfossils are shown in Fig. 1. Images on the left side of the figure depict the specimens studied along with the measurement spot. As in previously published micro-Raman spectra of organic-walled microfossils of varying age and state of preservation (see [1, $3,21]$ and references therein), the spectra reported here are characterized by two main lines at $\sim 1350$ and $\sim 1600 \mathrm{~cm}^{-1}$ given by the so-called "D" (disordered) and "G" (graphitic) bands. These spectral features can be attributed to molecular subunits of interlinked aromatic hydrocarbons [21]. It is important to notice that the position and shape of bands vary among the different specimens, even in those within the same sample, showing variability in the exact chemical composition of the specimens studied. For 

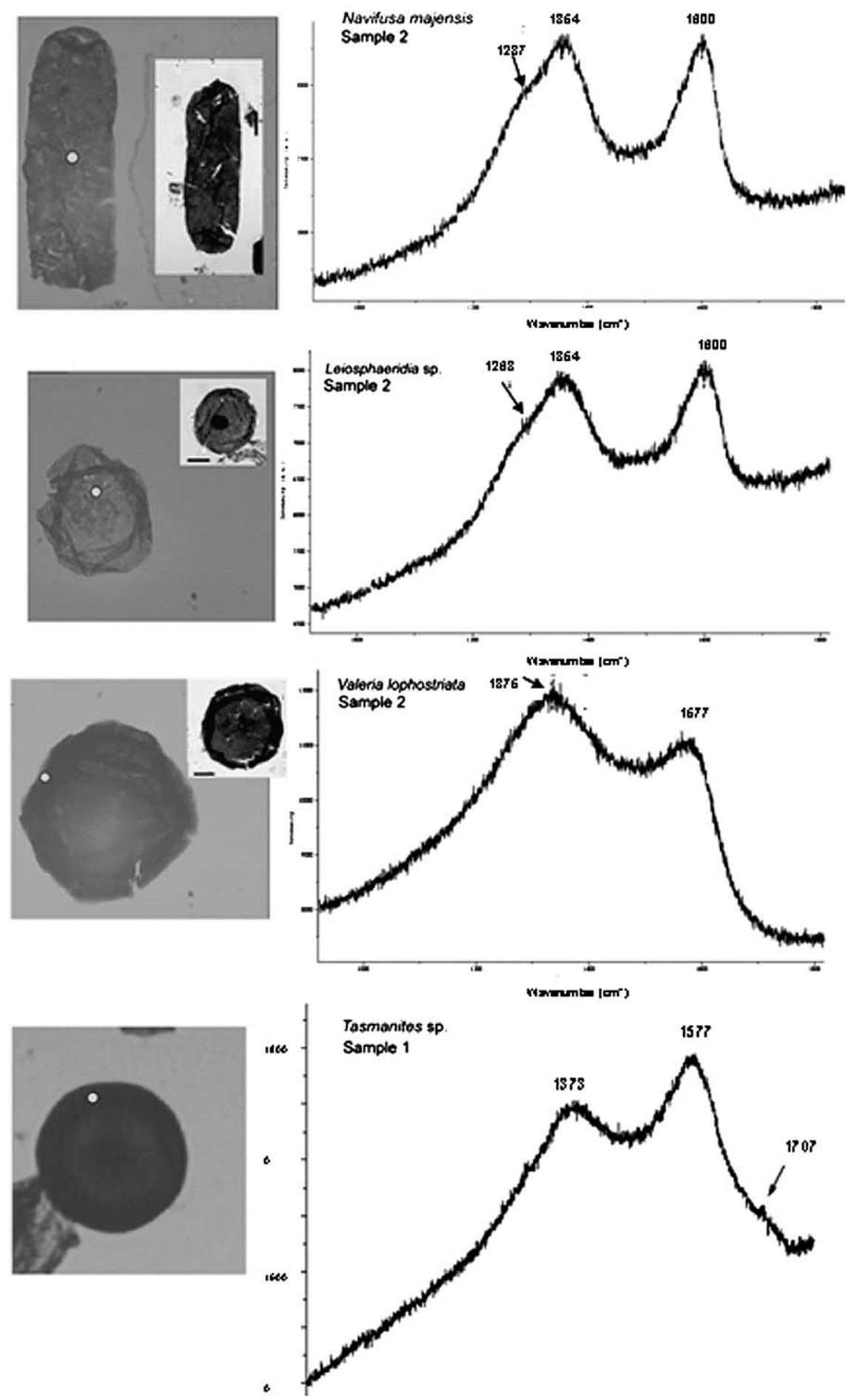

Fig. 1. Micro-Raman spectra from selected representative specimens of organic-walled microfossils of Neoproterozoic to early Palaeozoic age. (a)-(c) Neoproterozoic acritarchs from the Volta Basin (Ghana). (d) Tasmanites sp. from the Silurian sample of borehole A1-61 (Libya). On the left of each spectrum, the image of analyzed palynomorph and location of measurement spot is shown. 
instance, the position of the main peak in the "D" region is placed at $1354 \mathrm{~cm}^{-1}$ in Navifusa majensis and Leiosphaeridia sp., whereas in Valeria lophostriata it is placed at $1375 \mathrm{~cm}^{-1}$ (see Fig. 1). Similarly, the wavenumber of the "G" band is different, being $1600 \mathrm{~cm}^{-1}$ for the first two specimens and at $1577 \mathrm{~cm}^{-1}$ for Valeria lophostriata. It is interesting to note that the position of bands in the latter specimen is almost identical to those of the Raman spectrum of Tasmanites sp. (Sample 1), which is commonly attributed to the prasinophytes (Sample 1).

In addition, the Tasmanites specimen (see lower trace in Fig. 1) show a shoulder at $1707 \mathrm{~cm}^{-1}$, that can be attributed to one or more $\mathrm{C}=\mathrm{O}$ moieties, arising from ester, keto or other carbonyl molecular subunits. Such feature seems to be completely absent in spectra from acritarch specimens.

\section{Conclusions and perspectives}

These preliminary results show that micro-Raman spectroscopy can be effectively applied to isolated specimens of organic-walled microfossils extracted from pre-Cambrian and Palaeozoic rocks. Position and shape of spectral bands are shown to vary principally in relation with the nature (taxonomic rank and position) of the particular specimen considered. The differing spectral characteristic between acritarchs and the Tasmanites specimen (a taxon considered to belong to the Prasinophyceae class of green algae) demonstrate the potential for elucidating the nature of acritarchs and other enigmatic palynomorphs. Clearly, the amount of information that can be extracted from the experiments can be improved by more advanced data treatment techniques (e.g., calculation of the Raman index of preservation [21], chemometric treatment of spectral data) as well as by synergic use of additional analytical techniques, such as simultaneous application of vibrational spectroscopy techniques (Visible micro-Raman, UV micro-Raman, Micro-FTIR) and of different chemometrics strategies.

\section{Acknowledgements}

This study has been financially supported by a research Grant "CNRS-INSU 2009" awarded to M. Vecoli for the project: "The terrestrialization process: modelling complex interactions at the geosphere-biosphere interface". Neoproterozoic material was made available by a scientific collaboration with BRGM, France, which is greatly acknowledged.

\section{References}

[1] K.R. Arouri, P.F. Greenwood and M.R. Walter, Org. Geoch. 31 (2000), 75-89.

[2] M.D. Brasier, O.R. Green, A.P. Jephcoat, A.K. Kleppe, M.J. van Kranendonk, J.F. Lindsay, A. Steele and N.V. Grassineau, Nature 416 (2002), 76-81.

[3] J.-Y. Chen, J.W. Schopf, D.J. Bottjer, C.-Y. Zhang, A.B. Kudyavtsev, A.B. Tripathi, X.-Q. Wang, Y.-H. Yang, X. Gao and Y. Yang, Proc. Natl. Acad. Sci. USA 104 (2007), 6289-6292.

[4] G.K. Colbath and H.R. Grenfell, Rev. Palaeobot. Palynol. 86 (1995), 287-314.

[5] R. Coueffe and M. Vecoli, Precambrian Res., in press.

[6] S. Derenne, C. Largeau, C. Berkaloff, B. Rousseau, C. Wilhelm and P.G. Hatcher, Phytochemistry 31 (1992), $1923-1929$.

[7] C.B. Foster, J.D. Reed and R. Wicander, Geobios 22 (1989), 753-759.

[8] A.R. Hemsley, W.G. Chaloner, A.G. Scott and C.J. Groombridge, Ann. Bot. London 69 (1992), 545-549.

[9] H.J. Hofman and G.D. Jackson, Paleontological Soc. Mem. 37 (1994), 1-35.

[10] J.W. Huntley, S. Xiao and M. Kowalewski, Precambrian Res. 144 (2006), 52-68.

[11] J.C. Jagli and F. Paris, Rev. Palaeobot. Palynol. 118 (2002), 335-358. 
[12] E.J. Javaux, A.H. Knoll and M.R. Walter, Nature 412 (2001), 66-69.

[13] J. Kazmierczak and B. Kremer, Acta Palaeontol. Polonica 54 (2009), 541-551.

[14] D.M. Lamb, S.M. Auramik, D.J. Chapman and S. Zhu, Precambrian Res. 173 (2009), 93-104.

[15] R.E. Martin, Palaios 11 (1996), 209-219.

[16] R.M. Nagy, S.M. Porter, C.M. Dehler and Y. Shen, Nature Geoscience 2 (2009), 415-418.

[17] K.E. Peters, R. Ishiwatari and I.R. Kaplan, Am. Assoc. Petrol. Geol. Bull. 61 (1977), 504-510.

[18] W. Riegel, Rev. Palaeobot. Palynol. 148 (2008), 73-90.

[19] C. Rubinstein and P. Steemans, Rev. Palaeobot. Palynol. 118 (2002), 397-421.

[20] J.W. Schopf and A.B. Kudryavtsev, Precambrian Res. 173 (2009), 39-49.

[21] J.W. Schopf, A.B. Kudryavtsev, D.G. Agresti, A.D. Czaja and T.J. Wdowiak, Astrobiology 5 (2005), 333-371.

[22] J.W. Schopf, A.B. Kudryavtsev, A.D. Czaja and A.B. Tripathi, Precambrian Res. 158 (2007), 141-155.

[23] T. Servais, O. Lehnert, J. Li, G.L. Mullins, A. Munnecke, A. Nützel and M. Vecoli, Lethaia 41 (2008), 99-109.

[24] P.K. Strother, Rev. Micropal. 51 (2008), 9-21.

[25] P.K. Strother, G. Wood, W. Taylor and J. Beck, Mem. Ass. Australasian Palaeont. 29 (2004), 99-113.

[26] N.M. Talyzina and M. Moczydlowska, Rev. Palaeobot. Palynol. 112 (2000), 1-21.

[27] M. Vecoli and A. Le Hérissé, Earth Sci. Rev. 67 (2004), 267-311.

[28] M. Vecoli, O. Lehnert and T. Servais, Notebooks Geol. Mem. 2 (2005), 69-70.

[29] M. Vecoli, A. Riboulleau and J.G.M. Versteegh, Palaeogeogr. Palaeoclimatol. Palaeoecol. 273 (2009), 378-394.

[30] S. Willman and M. Moczydlowska, Lethaia 40 (2007), 111-123. 


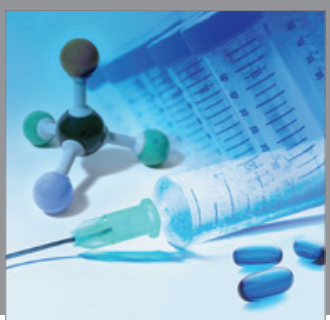

International Journal of

Medicinal Chemistry

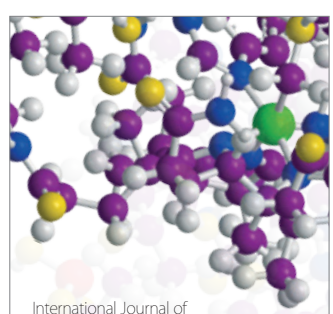

Carbohydrate Chemistry

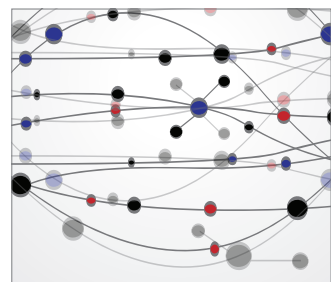

The Scientific World Journal
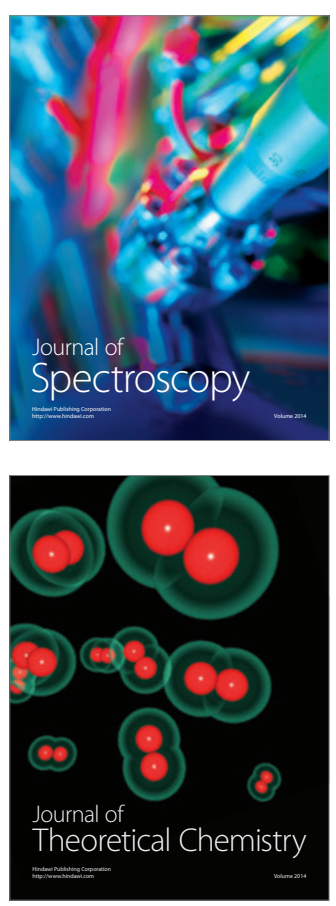
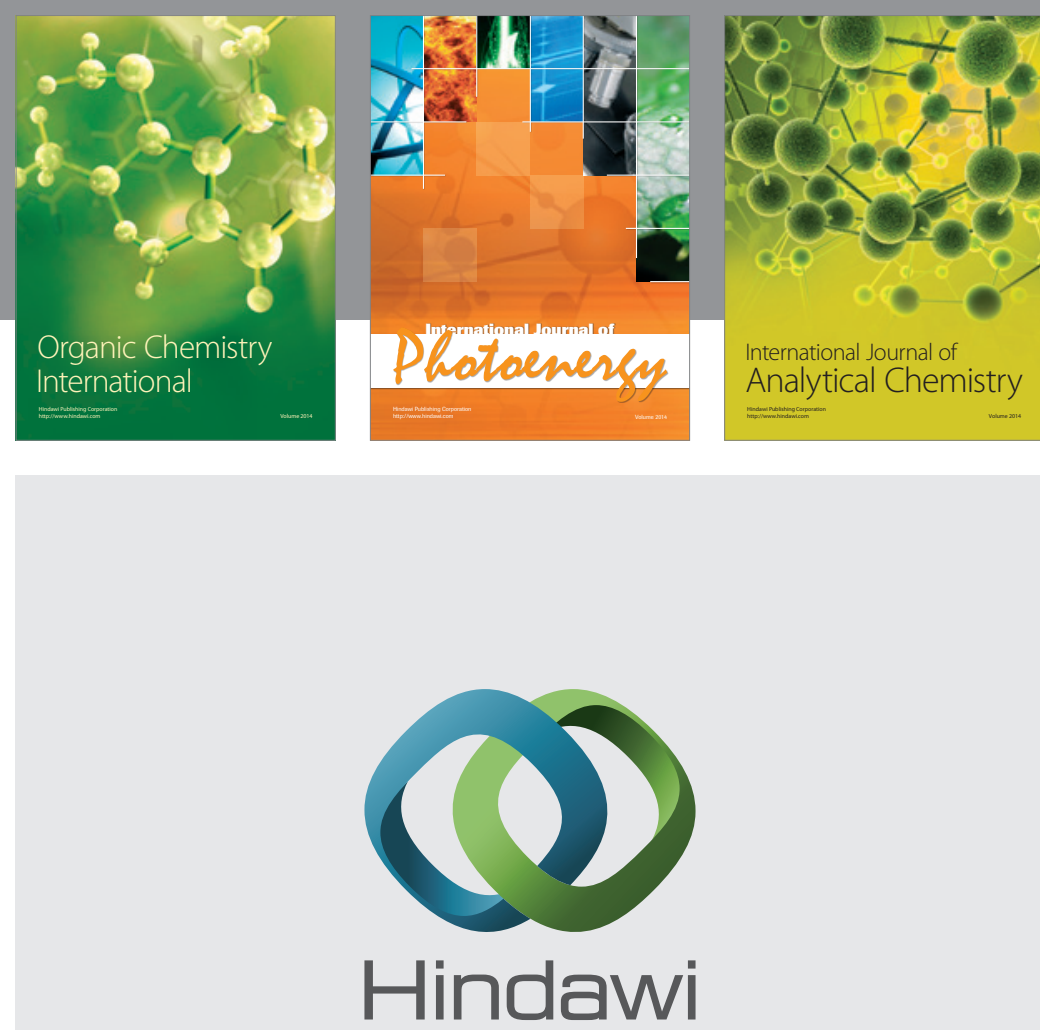

Submit your manuscripts at

http://www.hindawi.com
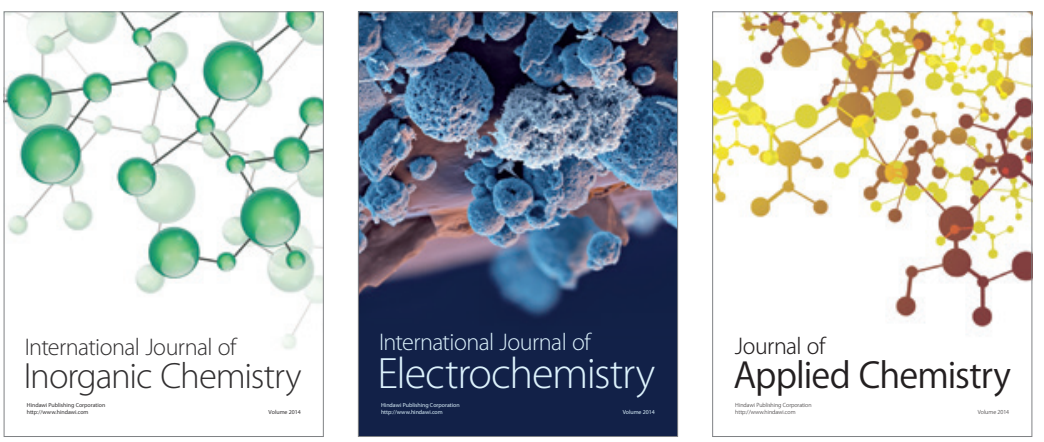

Journal of

Applied Chemistry
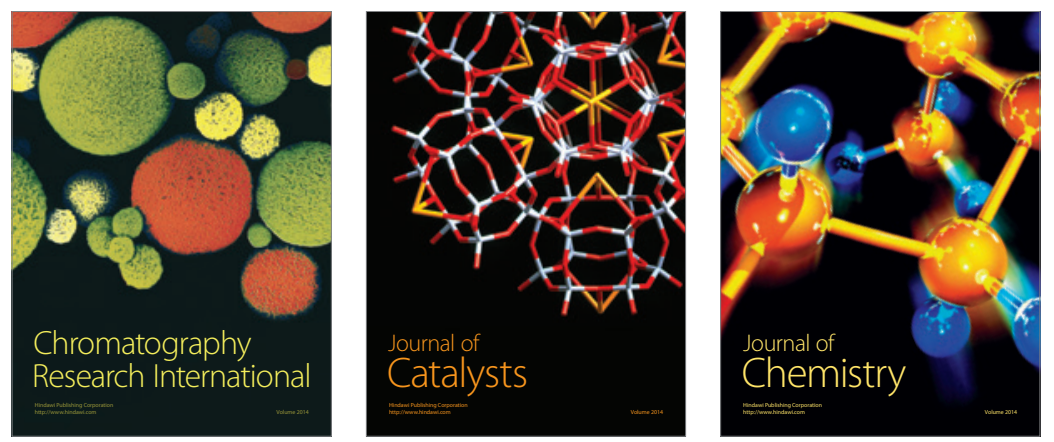
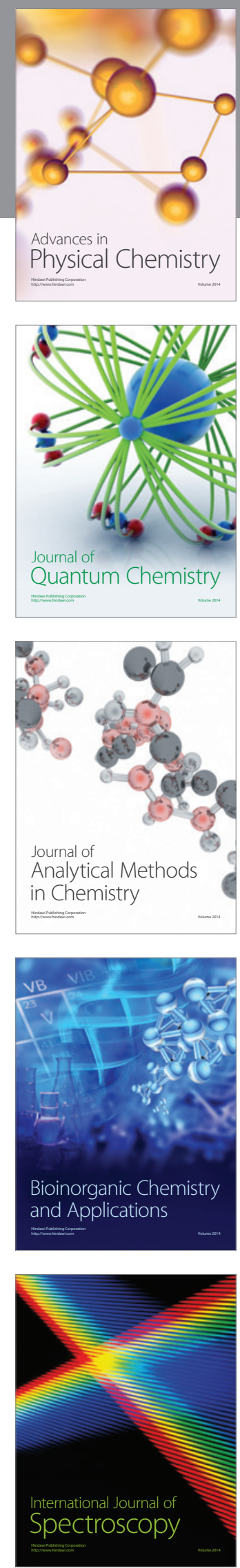